3. Петрова В. В., Калугина Д. А. Применение типографики для подготовки контента. Весник Московский государственный университет печати имени Ивапа Федорова. Москва, 2015. № 5. С. 19-21.

4. Беляев А. А. Актуальные проблемы современной вебтипографики: взгляд в будущее. Весник Московского ун-та. Сер. 10. Журналистика. Москва, 2010. № 3. С. 15-22.

5. Дизайн сайта и юзабилити: практический аспект. URL: https://griban.ru/blog/46-dizajn-sajta-i-juzabiliti-prakticheskij-aspekt.html (дата звернення: 15.11.2020).

6. Шрифты (фонты) корпоративного сайта. URL. http.//www.corpsite.ru/Encyclopedia/CreateSite/Design/Type.aspx (дата звернення: 17.11.2020).

DOI https://doi.org/10.30525/978-9934-26-004-9-102

\title{
ОСОБЛИВОСТІ РОЗРОБКИ КОЛЕКЦІЙ ДИТЯЧОГО ОДЯГУ ЗА ПРИНЦИПАМИ ЕКО-ДИЗАЙНУ
}

\author{
Векліч А. М. \\ аспірант факультету дизайну \\ Макалістер Т. O. \\ магістр факультету дизайну \\ Процик Б. О. \\ магістр факультету дизайну
}

Колосніченко О. В.

доктор мистеитвознавства, професор, професор кафедри художнього моделювання костюму

Пашкевич К. Л.

доктор технічних наук, професор,

професор кафедри ергономіки і дизайну

Київського начіонального університету технологій та дизайну м. Київ, Україна

Проблема забруднення навколишнього середовища в сучасному світі стоїть дуже гостро, зокрема одним із джерел негативного впливу є легка промисловість і таке явище як «швидка мода» (від англ. fast fashion). Ïї суть полягає у зміні асортименту одягу брендів по кілька разів протягом сезону, що перенасичує ринок товарами, знижуючи практичну 
цінність одягу $[1,2]$. Продукція «швидкої моди» втілює останні модні тенденції, що демонструються на світових модних показах в більш дешевому варіанті: недорогі матеріали та фурнітура, пошив більш низької якості, але це дає змогу споживачеві мас маркету купувати трендові речі за доступною ціною. Поряд із сегментом одягу для дорослих все більших масштабів набирає виробництво і продаж дитячого та підліткового одягу [3, 4]. Серед відомих брендів дитячого мас маркету Carters, Next, H\&M, Gap, Bershka та інші. Поширенню «швидкої моди» активно сприяють телебачення, інтернет-магазини, соціальні мережі, блогери тощо.

На противагу явищу «швидкої моди» одна 3 ідеологів стійкої моди Kate Flatcher пропонує концепцію «повільної моди» (з англ. slow fashion), що полягає в етичній практичності дизайну, якості товарів, підтримці місцевих виробників, правдивих цінах, свідомих методах дизайну, фокусі на збереженні ресурсів навколишнього середовища - усе це будує довгострокові відносини бренда та покупця [5].

В Україні рух свідомої моди представлений такими дизайнерами: Ksenia Schneider, RCR KHOMENKO, ULIULIA, Гореть, Голуб Upcycled Denim Project, Rehash, Veg Couture, COOM та інші. Ці бренди $\epsilon$ представниками концепціï Reduce-Reuse-Recycle та спрямовані на застосування екологічних підходів до виробництва, таких як: використання тканин з перероблених пластикових пляшок, перешивання речей, що вже були у використанні тощо.

Дитячий одяг, що також потрапляє під вплив модних тенденції та $\epsilon$ носієм екологічно негативного впливу мас маркету, має коротший термін експлуатації також через особливості фізіології дітей, а саме - постійний ріст. Виходячи 3 цього, можна зробити висновок, що для досягнення мети продовження терміну експлуатації дитячого одягу буде недостатнім дотримуватись принципів «повільної моди», також необхідним $\epsilon$ подовження часу відповідності розмірів одягу розмірам і фігурі дитини, щоб одяг був універсального розміру для певної розміро-зростової групи.

Нами проведено анкетне опитування дівчаток старшої шкільної групи та їхніх батьків, в результаті якого визначено, що $34 \%$ респондентів обирають спортивний стиль в дитячому одязі, найпопулярніша кольорова гама у $36 \%$ опитаних світла, у $25 \%$ - яскрава. В середньому споживачі купують одяг раз на місяць. Популярний асортимент одягу: світшоти $33 \%$ та футболки 25\%, куртки займають 14\%, спортивна сукня 14\%.

Для проектування одягу «універсального розміру» традиційно використовують наступні методи проектування: метод створення безрозмірного одягу та метод трансформації. Метод створення 
безрозмірного одягу - це різновид комбінаторного методу створення одягу, в якому головним є створення моделей на базі однієї моделі, яка підходить для людей різних розмірів завдяки правильному підбору конструктивних прибавок. До цього методу проектування можна віднести одяг «oversize», тобто речі вільного покрою, що виглядають завеликими на людині, яка їх носить, а також речі «оne size», спроектовані таким чином щоб на фігурах суміжних розміро-зростів мали однаково естетичний вигляд та були зручними в експлуатації. Проектування виробів за принципом «оne size» $є$ найбільш наближеним до традиційної практики виготовлення дитячих речей в спарених pозміро-зростах, в той час як одяг «оversize» в більшості є проявом модних тенденцій.

Трансформація - це метод перетворення однієї форми на іншу, а також трансформація елементів в рамках однієї форми, що містить такі способи: заміщення, додавання-відбирання, розгортання, зміна орієнтації, перестановка, зникнення-поява. Засоби трансформації, що виконують регулювальні функції, це застібки-блискавки, резинки, куліски, пояси, манжети тощо, часто використовуються в проектуванні дитячого одягу через можливість змінювати параметри виробу: довжини пілочки, спинки та рукавів, ширину по лінії талії тощо. До інноваційних методів можна віднести використання спеціально гофрованих тканин типу Petit Pli, які збільшують свої габаритні розміри при розтягуванні за рахунок розходження складок [6]. Такий метод має обмеження через необхідність використання спеціальних матеріалів, що мають високий рівень формостійкості і здатності до гофрування.

За результатами проведеного аналізу методів проектування одягу, універсального для певної розміро-зростової групи, було розроблено авторську колекцію повсякденного еко-одягу спортивного стилю для дівчат віком від 11,5 до 15,5 років «City Urban Jungle» (Рис. 1). Творчим джерелом колекції стали дороги, транспортні розв'язки, дорожні знаки та вуличні види спорту - скейтборд та баскетбол (Рис. 2). Для пошуку нових форм в колекції було також проведено трансформацію комерційно-успішних моделей одягу (Рис. 3). Моделі колекції спроектовано згідно методу створення безрозмірного одягу (за принципом «оne size») 3 елементами трансформації, що дозволяє збільшити термін їх експлуатації. Базовою силуетною формою колекції обрано трапецію 3 великою композиційною прибавкою. Основними композиційно-конструктивними рисами нових моделей стали: акцент на плечах, спущена лінія пройми та об'єм oversize, що відповідає стилістиці 80-х pp. XX ст., а також такі елементи як: накладні кишені, куліски для 
регулювання об'єму виробу, об'ємні рукава із вузькими манжетами тощо. Таким чином, унікальне функціональне конструктивне рішення моделей колекції дає можливість змінювати їх згідно із фізіологічними змінами дитини.

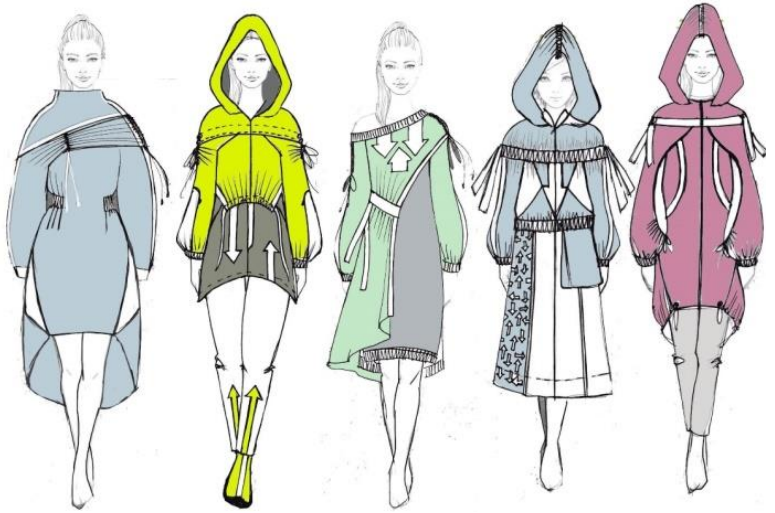

Рис. 1. Колекція еко-одягу для дівчат «City Urban Jungle»

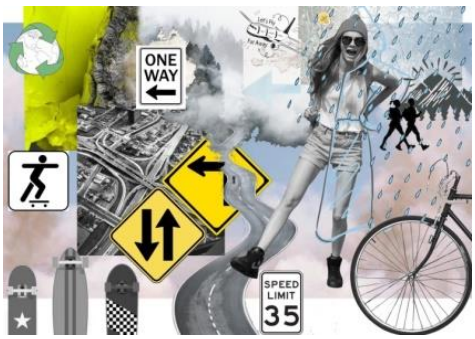

Рис. 2. Художній образ споживача

та джерела натхнення

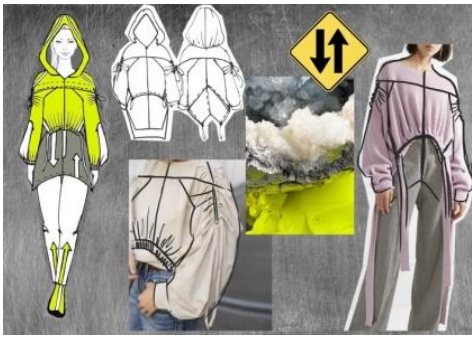

Рис. 3. Трансформація комерційно-успішних моделей одягу

Однією з важливих рис колекції «City Urban Jungle» стало оздоблення світло-рефлекторними стрічками та деталями, що особливо є актуальним при розробці дитячого одягу в контексті вирішення проблеми безпеки дітей на дорозі. Додатково сигнальну функцію виконують присутні в колекції тканини неонового кольору, використання яких також є однією 3 сучасних модних тенденцій.

Для виготовлення колекції було обрано тканини 3 переробленого пластику: плащова тканина, клейонка, тканина 3 мембраною, світло- 
рефлекторна тканина. 3 натуральних тканин був використаний ліоцелл (Lyocell) та льон. Розкладки лекал були спроектовані згідно принципу «zero waste» - 3 мінімальною площею міжлекальних випадів.

Висновки. Розглянуто методи проектування одягу, що застосовуються для подовження терміну його експлуатації, а саме, часу збереження відповідності розмірів виробу розмірам і фігурі дитини. Визначено, що для проектування дитячого одягу доцільно використовувати принцип «оne size» та елементи трансформації, що дозволяють виконувати певні регулювальні функції. За результатами проведеного аналізу створено колекцію еко-одягу для дівчат 3 використанням методів трансформації, що забезпечило більшу функціональність та універсальність за розміром для ширшого вікового діапазону дітей.

\section{Література:}

1. Pashkevych K.L., Khurana K., Kolosnichenko O.V., Kpotova T.F., Veklich A.M. Modern directions of eco-design in the fashion industry. Art and design. 2019. №4. C. 9-20. DOI: https://doi.org/10.30857/2617-0272.2019.4.1

2. Pashkevych K. L., Kolosnichenko O. V., Veklych A. M., Ovdiienko T. A. Current trends of the use of eco-materials in the design of light industry products. Art and design. 2019. № 3. C. 20-27. DOI: https://doi.org/10.30857/ 2617-0272.2019.3.2

3. Пашкевич К., Васильєва О., Герасименко О., Гальчинська О. Фактори зміни модних тенденцій в дизайні дитячого одягу. Scientific Letters of Academic Society of Michal Baludansky. Košice, Slovakia. 2020. Vol. 2. P. 36-40.

4. Yezhova O., Abramova O., Pashkevich K., Vasylieva O. Designing of children's stage costume using bionic objects. Fashion, Style \& Popular Culture. 2020. DOI: https://doi.org/10.1386/fspc_00053_1

5. Detox Fashion Supply Chain / Subramanian Senthilkannan Muthu Springer Nature Singapore Pte Ltd. 2017. C. 21.

6. Petit Pli : веб-сайт. URL: https://shop.petitpli.com/ (дата звернення 12.11.2020). 